\title{
PENYAKIT PULPA PADA PASIEN PENGUNJUNG POLIKLINIK GIGI DI RUMAH SAKIT UMUM DAERAH KOTA KOTAMOBAGU TAHUN 2016 - 2018
}

\author{
Mustapa Bidjuni ${ }^{1}$, I Ketut Harapan ${ }^{2}$ Suwandi ${ }^{3}$ \\ 1)2). Jurusan Kesehatan Gigi Poltekkes Kemenkes Manado \\ 3) Poliklinik Gigi RSUD Kota Kotamobagu Kab Bolaang Mogondow Sulawesi Utara. \\ Email : mustapabidjuni@gmail.com
}

\begin{abstract}
ABSTRAK
Pendahuluan : Penyakit Pulpa yang paling sering terjadi adalah karena iritan akibat invasi mikroorganisme atau produknya menuju pulpa melalui celah pada dentin yang di akibatkan karies, fraktur, penyebaran dari sulcus gingivalis atau abses periodontal. Faktor penyebab terjadinya kelainan pulpa diantaranya bakteri, mekanis, kimiawi, termal dan elektrik. Tujuan penelitian menggambarkan penyakit pulpa pada pasien pengunjung poliklinik gigi di Rumah Sakit Umum Daerah Kotamobagu Tahun 2016-2018. Metode: Metode yang digunakan dalam penelitian yaitu bersifat deskriptif menggunakan data sekunder berupa buku register kunjungan pasien. Waktu penelitian dilaksanakan pada bulan Juli 2019 yang bertempat pada poliklinik gigi RSUD Kota Kotamobagu. Adapun kriteria penilaian yaitu pasien penyakit pulpa yang dibedakan atas karakteristik umur dan jenis kelamin. Instrumen: Instrumen penelitian menggunakan format data tentang penyakit pulpa. Data yang diperoleh ditabulasi serta di sajikan dalam bentuk distribusi frekuensi persentase. Hasil: Hasil penelitian penelitian bahwa distribusi kunjungan penyakit pulpa paling tinggi pada tahun 2018 dengan jumlah kunjungan 1272 pasien. Berdasarkan umur kunjungan tertinggi yaitu umur 25-44 th pada tahun 2018 sebesar 495 (42,6\%), berdasarkan jenis kelamin tertinggi yaitu jenis kelamin perempuan pada tahun 2017 sebesar 755 (65\%). Kesimpulan: Kesimpulan dari penelitian ini menunjukkan bahwa pasien penyakit pulpa pada pasien yang berkunjung di poliklinik gigi RSUD Kotamobagu pada tahun 2016-2018 paling tinggi pada tahun 2018.
\end{abstract}

\section{Kata Kunci : Penyakit, Pulpa, Poliklinik}

\begin{abstract}
Introduction: Pulp disease is the most common cause of irritation due to invasion of microorganisms or products to the pulp through gaps in the dentin caused by caries, fractures, spread of sulcus gingivalis or periodontal abscesses. Factors causing pulp abnormalities include bacteria, mechanical, chemical, thermal and electrical. The purpose of this study is to describe pulp disease in patients visiting dental polyclinics at the Kotamobagu District General Hospital in 20162018. Methods: The method used in this research is descriptive using secondary data in the form of a patient visit register book. When the study was conducted in July 2019 which was housed in the dental clinic of Kotamobagu City Hospital. The assessment criteria are pulp disease patients, which are distinguished by age and sex characteristics. Instrument: The research instrument uses data formats about pulp disease. The data obtained are tabulated and presented in the form of a percentage frequency distribution. Results: The results of the research study that the distribution of pulp visits was highest in 2018 with a total of 1272 patient visits. Based on the age of the highest visit, namely the age of 25-44 years in 2018 amounted to 495 (42.6\%), based on the highest sex,
\end{abstract}


namely the sex of women in 2017 amounted to 755 (65\%). Conclusion: The conclusion of this study shows that patients with pulp disease in patients visiting the dental clinic at Kotamobagu Regional Hospital in 2016-2018 were highest in 2018.

Keywords: Pulp Disease, Polyclinic

\section{PENDAHULUAN}

Kesehatan adalah setiap kegiatan untuk memelihara dan meningkatkan kesehatan yang dilakukan oleh pemerintah dan atau masyarakat.Hal ini berarti bahwa peningkatan kesehatan ini, baik kesehatan individu, kelompok, atau masyarakat harus diupayakan.Upaya mewujudkan kesehatan ini dilakukan oleh individu, kelompok, masyarakat, lembaga pemerintah, ataupun lembaga swadaya masyarakat (LSM).Upaya mewujudkan kesehatan tersebut, dapat dilihat dari dua aspek, yakni pemeliharaan kesehatan dan peningkatan kesehatan.Pemeliharaan kesehatan mencakup dua aspek, yakni kuratif (pengobatan penyakit) dan rehabilitative (pemulihan kesehatan setelah sembuh dari sakit atau cacat). Sedangkan kesehatan mencakup dua aspek, yakni: preventif (pencegahan penyakit) dan promotif (peningkatan kesehatan itu sendiri). Kesehatan perlu ditingkatkan karena kesehatan itu relatif dan mempunyai bentangan yang luas. Oleh sebab itu upaya kesehatan promotif ini mengandung makna bahwa kesehatan seseorang, kelompok, atau individu harus selalu diupayakan sampai tingkat yang optimal. ${ }^{1}$

Penyakit pulpa menurut Profil Kesehatan Semarang Tahun 2013 termasuk kedalam 10 besar penyakit dengan prevalensi tinggi di rumah sakit. Etiologi penyakit pulpa yang paling sering adalah iritan akibat invasi mikroorganisme atau produknya menuju pulpa melalui celah pada dentin yang diakibatkan oleh karies, fraktur, penyebaran infeksi dari sulcus gingivalis, atau abscess periodontal. Berdasarkan kondisi pulpa, keparahan dan durasi iritan, serta respon host, pulpa dapat memberikan respon berupa reaksi inflamasi sehingga terjadi nekrosis atau kematian pulpa. $^{2}$

Pulpa gigi merupakan jaringan lunak dari bagian gigi umumnya garis luar jaringan pulpa mengikuti bentuk mahkota gigi dan bentuk luar saluran pulpa akar gigi. Pulpa gigi dalam kamar pulpa berasal dari jaringan mesenkim dan mempunyai berbagai fungsi sebagai pembentuk, sebagai penahan, mengandung zat-zat makanan, mengandung sel-sel saraf/sensori. Fungsi permukaan pulpa gigi adalah membentuk dentin. Sistem sensori yang kompleks dari pulpa gigi berfungsi mengontrol peredaran darah dan sensasi rasa sakit. Dentin reparasi atau dentiniritasi terbentuk sebagai penahan dari berbagai bentuk iritasi mekanis, khemis, atau bakteri. ${ }^{3}$

Riset Kesehatan Dasar (Riskesdas 2013) Prevalensi nasional masalah gigi dan mulut yaitu 25,9 persen, sebanyak 14 provinsi mempunyai masalah gigi dan mulut di atas angka nasional. Prevalensi DMF-T (Decay Missing Filling-Teeth) yaitu 4,6 sebanyak 15 provinsi memiliki prevalensi di atas prevalensi nasional. Indek DMF-T lebih tinggi pada perempuan $(5,0)$ dibanding lakilaki $(4,1)$ Indek DMF-T provinsi Sulawesi Utara 3,4, (Kemenkes, 2014). Hasil RISKESDAS 2018 menujukkan bahwa prevalensi nasional 57,6\% dan Sulawesi Utara lebih tinggi sebesar $66,5 \%$ dan menempati urutan kelima masalah kesehatan gigi dan mulut dari 34 provinsi. ${ }^{4}$

Tujuan penelitian mengetahui gambaran penyakit pulpa berdasarkan karakteristik 
JIGIM (Jurnal Ilmiah Gigi \& Mulut)

umur dan jenis kelamin pada pasien pengunjung pengunjung Poliklinik Gigi di Rumah Sakit Umum Daerah Kotamobagu Tahun 2016-2018.

\section{METODE :}

Jenis penelitian ini bersifat deskriptif dengan menggunakan data sekunder berupa buku register pengujung poliklinik gigi.

Waktu Penelitian dilaksanakan pada bulan Juli 2019 pada Poliklinik Gigi RSUD Kota Kotamobagu

Populasi penelitian: yang menjadi populasi dalam penelitian ini adalah seluruh pasien yang berkunjung dan memeriksakan gigi di Poliklinik Gigi RSUD Kotamobagu pada tahun 2016 - 2018 sejumlah 4.342 pasien. Sampel Penelitian: sampel penelitian seluruh pasien dengan penyakit pulpa pada pasien pengunjung poliklinik gigi di RSUD Kotamobagu tahun 2016-2018 sejumlah 2.840 kasus penyakit pulpa dengan kriteria : pasien umur 4 tahun sd $>65$ tahun dan jenis kelamin.

Instrumen Penelitian: Instrumen penelitian menggunakan, buku register kunjungan poliklinik gigi tahun 2016-2018, alat tulis menulis, format tabulasi data. Analisa Data: analisa data yang didapat disajikan dalam bentuk tabel distribusi Frekuensi.

\section{HASIL}

Distribusi Penderita Penyakit Pulpa di Poliklinik Gigi RSUD Kotamobagu tahun 2016 - 2018 dapat dilihat pada tabel berikut:
Bidjuni M,dkk, Penyakit Pulpa

Tabel 1. Data Penyakit Pulpa di Poliklinik

Gigi Tahun 2016 - 2018

\begin{tabular}{ccc}
\hline Tahun & $\begin{array}{c}\text { Penyakit } \\
\text { Pulpa }\end{array}$ & $\begin{array}{c}\text { Persentase } \\
(\%)\end{array}$ \\
\hline 2016 & 407 & 14.3 \\
2017 & 1.161 & 40.9 \\
2018 & 1.272 & 44.8 \\
\hline Total & 2.840 & 100 \\
\hline
\end{tabular}

Berdasarkan data penderita penyakit pulpa pada tahun 2016 - 2018 terjadi kenaikan yang signifikan pada kasus kunjungan penyakit pulpa. Dimana pada tahun 2016 penderita penyakit pulpa sebanyak 407 kasus, tahun 2017 sebanyak 1.161 kasus dan pada tahun 2018 sebanyak 1.272 kasus.

Distribusi penderita penyakit pulpa berdasarkan kelompok umur di poliklinik gigi RSUD Kotamobagu dapat dilihat pada tabel 2 berikut :

Tabel 2. Distribusi Penderita Penyakit Pulpa Berdasarkan Kelompok Umur di Poliklinik Gigi RSUD Kotamobagu Tahun 2016 - 2018

\begin{tabular}{|c|c|c|c|c|c|c|c|c|c|c|}
\hline \multirow{2}{*}{ Tahun } & \multicolumn{10}{c|}{ Kelompok umur (Tahun ) } \\
\cline { 2 - 13 } & $\mathbf{4 - 1 4}$ & $\mathbf{1 5 - 2 4}$ & $\mathbf{2 5}-\mathbf{4 4}$ & $\mathbf{\%}$ & $\mathbf{4 5 - 6 4}$ & $\mathbf{2}$ & $\mathbf{7 6 5}$ & $\mathbf{\%}$ \\
\hline 2016 & 47 & 14.6 & 75 & 13 & 191 & 16.2 & 91 & 13.9 & 3 & 2.8 \\
\hline 2017 & 120 & 37.4 & 247 & 42.5 & 495 & 42.1 & 250 & 38.2 & 48 & 44.9 \\
\hline 2018 & 154 & 48 & 259 & 44.5 & 490 & 41.7 & 313 & 47.9 & 56 & 52.3 \\
\hline Total & $\mathbf{3 2 1}$ & $\mathbf{1 0 0}$ & $\mathbf{5 8 1}$ & $\mathbf{1 0 0}$ & $\mathbf{1 1 7 6}$ & $\mathbf{1 0 0}$ & $\mathbf{6 5 4}$ & $\mathbf{1 0 0}$ & $\mathbf{1 0 7}$ & $\mathbf{1 0 0}$ \\
\hline
\end{tabular}

Berdasarkan data diatas distribusi penyakit pulpa kunjungan terbanyak pada kelompok umur 25 - 44 tahun, dimana tahun 2016 sebanyak 191 (16,2\%) tahun 2017 sebanyak 495 ( 42,1\%) dan pada tahun 2018 sebanyak $490(41,7 \%)$ sedangkan untuk distribusi penderita terendah pada kelompok umur $>65$, dimana pada tahun 2016 sebanyak 3( 2,8\%) tahun 2017 sebanyak 48( 44,9\%) dan pada tahun 2018 sebanyak 56 ( 52,3\%). 
JIGIM (Jurnal Ilmiah Gigi \& Mulut)

Distribusi penderita penyakit pulpa berdasarkan jenis kelamin di poliklinik gigi RSUD Kotamobagu dapat di lihat pada tabel.3 sebagai berikut:

Tabel 3. Distribusi Penderita Penyakit Pulpa

Berdasarkan Jenis Kelamin di Poliklinik

Gigi RSUD Kotamobagu Tahun 2016 - 2018.

\begin{tabular}{|c|c|c|c|c|c|c|}
\hline Tahun & Laki-Laki & \% & Perempuan & \% & Jumlah & \% \\
\hline 2016 & 159 & 14.2 & 248 & 14.5 & 407 & 14.3 \\
\hline 2017 & 406 & 36.1 & 755 & 44 & 1.161 & 40.9 \\
\hline 2018 & 560 & 49.7 & 712 & 41.5 & 1.272 & 44.8 \\
\hline Total & $\mathbf{1 . 1 2 5}$ & $\mathbf{1 0 0}$ & $\mathbf{1 . 7 1 5}$ & $\mathbf{1 0 0}$ & $\mathbf{2 . 8 4}$ & $\mathbf{1 0 0}$ \\
\hline
\end{tabular}

Data pada tabel 3 menunjukkan distribusi penderita penyakit pulpa berdasarkan jenis kelamin tertinggi yaitu perempuan dimana pada tahun 2016 sebanyak $248(14,5 \%)$ tahun 2017 sebanyak 755 (44 $\%$ ) dan tahun 2018 sebanyak 712 ( 41,5\%) sedangkan distribusi penyakit pulpa terendah adalah laki -laki yaitu pada tahun 2016 sebanyak $159(14,2 \%)$ tahun 2017 sebanyak 406 (406\%) dan pada tahun 2018 sebanyak $560(49,7 \%)$.

Distribusi penderita penyakit pulpa berdasarkan vital dan non vital di poliklinik gigi RSUD Kotamobagu dapat dilihat pada tabel 4 di bawah ini :

Tabel 4 .Distribusi Penderita Penyakit Pulpa Berdasarkan Vital dan Non Vital Poliklinik gigi RSUD Kotamobagu tahun 2016-2018

\begin{tabular}{|c|c|c|c|c|c|}
\hline \multirow{2}{*}{ Tahun } & Pulpa & $\%$ & Pulpa & $\%$ & Jumlah \\
\hline & Vital & & Non Vital & & \\
\hline 2016 & 302 & 13.6 & 105 & 16.8 & 407 \\
\hline 2017 & 892 & 40.2 & 269 & 43.2 & 1.161 \\
\hline 2018 & 1.023 & 46.2 & 249 & 40 & 1.272 \\
\hline Total & 2.217 & 100 & 623 & 100 & 2.48 \\
\hline
\end{tabular}

Data pada tabel 4 menunjukkan distribusi penderita penyakit pulpa berdasarkan vital dan non vital bahwa sebagian besar kunjungan penyakit pulpa
Bidjuni M,dkk, Penyakit Pulpa

masih dalam keadaan vital dimana pada tahun 2016 sebanyak $302(13,6 \%)$ tahun 2017 sebanyak $892(40,2 \%)$ dan tahun 2018 Sebanyak 1023 ( 46,2 \%) sedangkan yang terendah adalah non vital pada tahun 2016 sebanyak 105 ( 16,8\%) tahun 2017 sebanyak $269(43,2 \%)$ dan pada tahun 2018 sebanyak $249(40 \%)$.

\section{PEMBAHASAN}

Berdasarkan hasil penelitian yang dilakukan di poliklinik gigi RSUD Kotamobagu didapatkan bahwa kunjungan penderita maupun kasus penyakit pulpa dari tahun 2016 sampai dengan tahun 2018 terjadi peningkatan kunjungan yang signifikan dengan total kunjungan 4.342 pasien dan kasus penyakit pulpa sebanyak 2.840 hal ini di sebabkan karena masih kurangnya pengetahuan dan kesadaran masyarakat akan kesehatan gigi dan mulut. Pasien rata-rata akan berobat kedokter gigi atau ke fasilitas kesehatan gigi lainnya apabila telah mengalami rasa sakit sekali atau adanya rasa kurang nyaman seperti bau yang tidak enak. Apabila hanya sebatas sakit ringan atau sakit yang bisa di hilangkan dengan obat, pasien lebih memilih merawat dan menyembuhkan sendiri. Ditambah adanya rujukan pasien dari daerah Bolaang mongondow raya dan sebagian di Kabupaten Minahasa selatan.

Dalam hal usia selalu terkait dengan masalah kesehatan gigi dan mulut terutama pada penyakit pulpa. Hasil penelitian menunjukkan pada (tabel 3) bahwa distribusi berdasakan karekteristik umur penderita pada tahun 2016 - 2018 yang tertinggi adalah kelompok umur 25-44 th sebanyak 931 $(32,8 \%)$. Pada kelompok umur ini merupakan masa yang paling beresiko terkena karies gigi khususnya pada gigi molar 2 dan molar 3 . 
JIGIM (Jurnal Ilmiah Gigi \& Mulut)

Semakin bertambahnya usia seseorang maka kemungkinan terjadinya karies gigi akan semakin meningkat, hal inilah yang menyebabkan kemungkinan kejadian karies pada umur tersebut tinggi. Usia yang semakin tua mengkaibatkan paparan makanan nyang mengndung gula dan bersifat kariogenik terhadap gigi semakin lama, apabila kebersihan gigi dan mulut diabaikan maka gigi akan mudah mengalami demineralisasi sehingga karies dapat terjadi. Juga kemungkinan waktu menyikat gigi tidak tepat dan kontrol kesehatan gigi dan mulut bila sudah ada keluhan. ${ }^{5}$

Faktor jenis kelamin ikut mempengaruhi terjadinya penyakit pulpa. Dari penelitian (tabel 4) pada tahun 2016 - 2018 kunjungan tertinggi pada jenis kelamin perempuan sebanyak $1.715(60,4 \%)$. Hal ini bisa disebabkan karena perempuan lebih suka mengkonsumsi makanan yang manis sehingga gigi lebih sering terpapar dengan makanan yang kariogenik yang dapat menyebabkan karies. Penelitian yang dlakukan oleh Sihombing (2009) bahwa perempuan lebih cenderung menderita karies gigi dipengaruhi oeh 3 faktor, pertama masa erupsi gigi yang lebih cepat dibanding dengan laki -laki sehingga lebih lama terpapar dengan makanan kariogenik, kedua kemudahan bagi wanita untuk memperoleh makanan sehingga proses deminelasisasi enamel sangat singkat, ketiga masa kehamilan pada masa ini kebutuhan terhadap nutrisi terutama kalsium semakin meningkat dua kali lipat karena nutrisi tersebut juga dibutuhkan untuk tumbuh kembang gigi dan tulang janin. ${ }^{6}$ Pada saat masa kehamilan ini didapatkan bahwa sebagian besar ibu hamil belum banyak memperoleh pengertian tentang kesehatan gigi dan mulut yang berakibat malas menjaga kebersihan mulut serta menggosok gigi secaara teratur. ${ }^{7}$ Minimnya pengetahuan dan

\section{Bidjuni M,dkk, Penyakit Pulpa}

perilaku menjaga kebersihan gigi dan mulut, juga pola makan yang cenderung mengkonsumsi makanan yang manis sehingga prosses demineralisasi oleh bakteri pada gigi lebih cepat berkembang biak dan menyebabkan karies gigi. ${ }^{9}$

Pada tabel 5 menujukkan bahwa kunjungan penyakit pulpa berdasarkan vital dan non vital tahun 2016 -2018 terbanyak adalah masih pulpa vital sebanyak 2.217 kasus. Hal ini di karenakan masih kurangnya pengetahuan dan kesadaran masyarakat akan kesehatan gigi dan mulut. Pasien rata-rata akan berobat ke dokter gigi atau ke fasilitas kesehatan gigi lainnya apabila telah mengalami rasa sakit sekali atau adanya rasa kurang nyaman seperti bau yang tidak enak.

\section{KESIMPULAN}

Berdasarkan hasil penelitian dapat disimpulkan bahwa;

a. Distribusi penyakit pulpa pada pasien pengunjung di poliklinik gigi selang tahun 2016-2018 mengalami peningkaatan dan tertinggi pada tahun 2018 dengan jumlah 1.272 .

b. Distribusi penyakit pulpa berdasarkan umur selang tahun 2016 - 2018 yang tertinggi pada tahun 2018 adalah kelompok umur 25 - 44 tahun dengan jumlah $490(38,5 \%)$.

c. Distribusi penyakit pulpa berdasarkan jenis kelamin pada pasien pengunjung di poliklinik gigi selang tahun 2016 - 2018 yang tertinggi pada tahun 2017 adalah perempuan sebanyak $755(65 \%)$.

d. Distribusi penyakit pulpa berdasarkan vital dan non vital pada pasien pengunjung poliklinik gigi selang tahun 2016-2018 yang tertinggi adalah tahun $20181.023(46,2 \%)$. 
SARAN

Bagi petugas poli gigi RSUD

Kotamobagu diharapkan dengan adanya informasi mengenai gambaran penyakit pulpa pada pengunjung poliklinik gigi ini dapat digunakan sebagai acuan untuk meningkatkan pelayanan kesehatan gigi dan mulut baik pencegahan berupa penyuluhan penyakit pulpa dan akibatnya, upaya kuratif berupa perawatan penyakit pulpa. Kepada pemerintah daerah melalui dinas kesehatan untuk lebih meningkatkan usaha promosi kesehatan pada masyarakat dan anak anak sekolah melalui kegiatan UKGS dan UKGMD serta kerja sama antar program khusunya KIA di puskesmas.

\section{DAFTAR PUSTAKA}

1. Notoadmojo.S . Pendidikan dan Perilaku Kesehatan. PT. Rineke Cipta Jakarta

2. Vania,S. (2013) Efek Anti Bacterial Ekstrak Etanol Siwak Terhadap Pertumbuhan Bakteri Porphyromonas Gingivalis. Skripsi. Fakultas Kedokteran Gigi Universitas Jember.

3. Wangidjaja ,I. (1991) Anatomi Gigi, edisi 2 EGC Jakarta.

4. Kementrian Kesehatan RI. (2013) Riset Kesehatan Dasar, Badan Penelitian dan Pengembangan Tenaga Kesehatan .Jakarta.

5. Tarigan ,R. (2006) Perawatan Pulpa Gigi ,EGC Jakarta

6. Sihombing, J. (2009) .Karakteristik Penderita Karies Gigi Yang Berobat di Rumah Sakit Dr Pirngadi Medan. PT. Raja Grafindo Persada, Jakarta.

7. Machfoedz,I dan Zein, Y.A (2005) . Menjaga Kebersihan Gigi dan Mulut Anak- anak dan Ibu Hamil . Fitamaya , Yogakarta.

8. Bahar, A. (2011). Paradigma Baru Pencegahan Karies Gigi.Lembaga Penerbit Universitas Indonesia. Jakarta 